\title{
Hypertrophic osteoarthropathy associated with carcinoma of the oesophagus
}

\author{
R. S. Maurice-Williams \\ M.A., M.B., B.Chir (Cantab.) \\ House-Physician, Addenbrooke's Hospital, \\ Cambridge
}

\author{
R. J. WILSON* \\ M.B., Ch.B., M.R.C.P., M.R.C.P. (Ed.) \\ Senior Registrar, Addenbrooke's Hospital, \\ Cambridge
}

HYPERTROPHIC osteoarthropathy is an uncommon condition, almost always associated with primary malignancy of the lung or pleura. It has rarely been reported in association with lesions of the upper gastro-intestinal tract, with or without pulmonary metastases. In this paper we describe the syndrome occurring in conjunction with carcinoma of the oesophagus.

\section{Case report}

A 69-year-old woman was admitted to hospital in April 1968 with a history of progressive dysphagia, weight loss of $42 \mathrm{lb}$, ankle swelling over a period of 3 months, and a productive cough for 1 month. Previously she had been well apart from recurrent urinary infection.

On examination she was grossly emaciated, the facial features were coarse and leonine and the limb extremities were warm, with marked clubbing of the fingers and toes. There was bilateral pitting oedema below the knees. A soft midline thyroid cyst was noted. Coarse crepitations were present at both lung bases. There was no lymphadenopathy, and no abnormalities of the abdomen, nervous system, or cardiovascular system were noted.

Investigations. Haemoglobin was $11.8 \mathrm{~g} / 100 \mathrm{ml}$, white cell count $8000 / \mathrm{mm}^{3}$, MCHC $31 \%$ and ESR $83 \mathrm{~mm}$ in the 1st hour (Westergren). Plasma bicarbonate was $31 \mathrm{mEq} / 1$, sodium $132 \mathrm{mEq} / \mathrm{l}$, potassium $2.9 \mathrm{mEq} / 1$ and blood urea $22 \mathrm{mg} / 100 \mathrm{ml}$. Serum calcium was $9.6 \mathrm{mg} / 100 \mathrm{ml}$, inorganic phosphate $4.3 \mathrm{mg} / 100 \mathrm{ml}$ and alkaline phosphatase 10 King-Armstrong units. SGPT was 8 units $/ \mathrm{ml}$ and the serum total protein $6.2 \mathrm{~g} / 100 \mathrm{ml}$. A chest X-ray showed mediastinal widening, an opacity at the right lung base and a second opacity at the left lung apex. A barium swallow showed almost complete oesophageal obstruction just below the level of the carina. Below the obstruction the oesophageal lumen was very narrow and distorted. Above it was dilated and projecting into the right side of the mediastinum. A skeletal survey showed subperiosteal

* Present address: Addenbrooke's Hospital, Trumpington Street, Cambridge. new bone deposition at the distal thirds of the forearm long bones, the entire shafts of the tibiae and fibulae, and the proximal phalanges of the right middle fingers.

The patient died soon after admission. At postmortem she was found to have a carcinoma of the oesophagus with two pulmonary and two hepatic metastases. The primary tumour consisted of a pedunculated polyp, $10 \mathrm{~cm}$ long and $2.5 \mathrm{~cm}$ wide, arising from soft raised neoplastic tissue at the junction of the lower and middle thirds of the oesophagus. Histological examination showed a nonkeratinizing squamous-cell carcinoma with some fibrous stroma. Locally it had spread through the muscle-coat of the oesophagus into the surrounding connective tissue. The pulmonary metastases were 2 and $3 \mathrm{~cm}$ in diameter.

\section{Discussion}

The full syndrome of hypertrophic osteoarthropathy (HOA) comprises clubbing of the fingers and toes, soft tissue swelling of the distal portions of the limbs, in particular around the distal large joints, which may exhibit painful effusions, a coarsening and overgrowth of the facial features, and the deposition of subperiosteal new bone, which typically, is separated from the older cortex by a radiotranslucent zone (Ginsburg, 1963).

About $90 \%$ of cases of HOA are associated with primary malignant tumours of the lungs or pleura (Ginsburg, 1963) and the incidence of HOA amongst primary pulmonary malignancies has been estimated at around 5\% (Yacoub, 1965). HOA has been occsionally reported in association with a wide variety of conditions, including empyema and lung abscess, pulmonary fibrosis, bone tuberculosis, Hodgkin's disease of the lungs, steatorrhoea (Hammarsten \& O'Leary, 1957), pulmonary tuberculosis (Wierman, Clagett \& McDonald, 1954), portal cirrhosis (Buchan \& Mitchell, 1967), carcinoma of the thymus (Miller, 1939) and cervix (Ives, 1963) and successive pregnancies (Cullen \& Maskeny, 1966). A familial form (pachydermoperiostosis) of HOA occurs (Vogl \& Goldfischer, 1962). 
HOA has been described in association with upper gastro-intestinal neoplasms on very few occasions. We have been able to find eight cases reported with nasopharyngeal malignancies (Yacoub, Simon \& Ohnsorge, 1967), two with carcinoma of the stomach (Singh, Jolly \& Bansal, 1962; Yacoub et al., 1967) and five with carcinoma of the oesophagus (Cayla, Guérard des Lauriers \& Coste, 1962; Coury, 1962; Peyman, 1959). In addition two cases have been reported with benign oesophageal polyps (Joplin \& Fraser, 1965; Hollis, 1967) and one with achalasia of the cardia alone (Preble, 1898). The other cases reported with carcinoma of the oesophagus were, like ours, bulky growths with mediastinal infiltration but unlike ours, without evidence of lung metastases. In the case of the benign polyps, the HOA regressed rapidly following excision of the tumours. Yacoub et al. (1967) collected forty-one cases from the literature in which HOA was associated with lung metastases from non-pulmonary tumours. Twenty of these were from osteo- or fibrosarcomata, eight were from nasopharyngeal tumours and one was from carcinoma of the stomach. Aufses \& Aufses (1960) found no case of HOA amongst 883 patients with lung secondaries.

The pathogenesis of HOA remains obscure though it is known that there is an increased urinary excretion of oestrogens (Ginsburg \& Brown, 1961), and increase in blood flow in the forearms and calves (Ginsburg, 1958). In one case, a greatly increased plasma level of human growth hormone was found (Steiner, Dahlback \& Waldenström, 1968), and the fall to normal levels after resection of the associated bronchial adenocarcinoma paralleled the regression of symptoms of the osteoarthropathy. In man, vagotomy leads to immediate relief of symptoms (Flavell, 1956), but atropinization (Holling \& Brodey, 1961) or sympathectomy (Holling, Brodey \& Boland, 1961) are without effect.

\section{Acknowledgments}

We should like to thank Professor I. H. Mills for permission to report this case, and also Dr D. McC. Gregg, Consultant Radiologist, and Dr P. Millard (Cambridge University Department of Pathology) for permission to publish their radiological and post-mortem findings.

\section{References}

Aufses, A.M. \& Aufses, B.M. (1960) Hypertrophic osteoarthropathy in association with pulmonary metastases from extrathoracic malignancies. Dis. Chest. 38, 399.

Buchan, D.J. \& Mitchell, D.M. (1967) Hypertrophic osteoarthropathy in portal cirrhosis. Ann. intern. Med. 66, 130.

Cayla, J., Guérard des Lauriers, A. \& Coste, F. (1962) Ostéoarthropathie hypertrophiante et cancer de l'oesophage. Bull. Soc. Méd. Hop., Paris, 113, 294.

Coury, M. (1962) Ostéoarthropathie hypertrophiante pneumique et cancer de l'oesophage. Bull. Soc. Méd. Hop., Paris, 113, 335.

Cullen, D.R. \& Maskeny, P.J.K. (1966) Clubbing of the fingers and hypertrophic osteoarthropathy in pregnancy. Lancet, ii, 473.

FlavelL, G. (1956) Reversal of pulmonary hypertrophic osteoarthropathy by vagotomy. Lancet, i, 260.

GinsBURG, J. (1958) Observations on the peripheral circulation in hypertrophic pulmonary osteoarthropathy. Quart. J. Med. 27, 335.

GiNSBURG, J. (1963) Hypertrophic pulmonary osteoarthropathy (review). Postgrad. med. J. 39, 639.

GinsBURG, J. \& BROWN, J.B. (1961) Increased oestrogen excretion in hypertrophic pulmonary osteoarthropathy. Lancet, ii, 1274.

Hammarsten, J.F. \& O'Leary, J. (1957) Hypertrophic pulmonary osteoarthropathy. Arch. intern. Med. 99, 431.

Holling, H.E. \& BRODEY, R.S. (1961) Pulmonary hypertrophic osteoarthropathy. J. Amer. med. Ass. 178, 977.

Holling, H.E., Brodey, R.S. \& Boland, H.C. (1961) Pulmonary hypertrophic osteoarthropathy. Lancet, ii, 1269.

Hollis, W.C. (1967) Hypertrophic osteoarthropathy secondary to upper gastrointestinal tract neoplasms. Ann intern. Med. 66, 125.

IVES, F.A. (1963) Metastatic carcinoma of cervix with acanthosis nigricans, bullous pemphigoid and hypertrophic pulmonary osteoarthropathy. Proc. Roy. Soc. Med. 56, 910.

JoPlin, G.F. \& Fraser, T.R. (1965) Oesophageal polyp with hypertrophic osteoarthropathy. Proc. Roy. Soc. Med. 58, 576.

Miller, E.R. (1939) Carcinoma of thymus associated with marked pulmonary osteoarthropathy. Radiology, 32, 651 .

Peyman, M.A. (1959) Achalasia of cardia, carcinoma of the oesophagus, and hypertrophic pulmonary osteoarthropathy. Brit. med. J. 1, 23.

Preble, R.B. (1898) A case of hypertrophic osteoarthropathy with achalasia of the cardia. J. Amer. med. Ass. 30, 217.

Singh, A., Jolly, S.S. \& Bansal, B.B. (1960) Hypertrophic osteoarthropathy associated with carcinoma of the stomach. Brit. med. J. 2, 581.

Steiner, H., Dahlbäck, O. \& Waldenström, J. (1968) Ectopic growth hormone production and osteoarthropathy in carcinoma of the bronchus. Lancet, i, 783.

VoGL, J. \& Goldfischer, J. (1962) Pachydermoperiostosis. Amer. J. Med. 33, 166.

Wierman, W.H., Clagett, O.T. \& McDonald, J.R. (1954) Articular manifestations in pulmonary disease. J. Amer. med. Ass. 155, 1459.

YACOUB, M.H. (1965) The relation between the histology of bronchial carcinoma and hypertrophic pulmonary osteoarthropathy. Thorax, 20, 537.

Yacoub, M.H., Simon, G. \& OhnSORge, J. (1967) Hypertrophic osteoarthropathy in association with pulmonary metastases from extrathoracic tumours. Thorax, 22, 226. 